\title{
How Do Gifted Children Of Various Ages Perceive Their Situation In Heterogeneous Classes And What Can Pre-Service Teachers Learn From Them?
}

Rama Klavir, Kaye College of Education, Israel

\begin{abstract}
During their teaching program, pre-service teachers participated in a course concerning teaching in the heterogeneous classroom. As an introduction to the issue of 'gifted children', the preservice teachers were given an assignment: (1) to interview gifted children (identified as gifted by the Ministry of Education, according to IQ level) in their own classes or schools, about their situation in the heterogeneous class or school. (2) To write a personal reflection about what they learned from these interviews. These data provided the basis for the study of the unique needs of 'gifted children' and the responses of pre-service teachers to these issues. The present study is based on the analysis of these collective results. On the one hand, it presents the picture obtained by the pre-service teachers from analysis of their interviews (Part I). On the other, the study presents the analysis of the pre-service teachers' responses to Part II of the assignment.
\end{abstract}

Gifted Pupils: Who Are They?

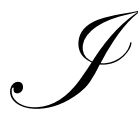

ntellectually gifted children are defined as excellent pupils in terms of their general high abilities, as determined by intelligence tests. Their excellence, however, is relative (Klavir, 2001). When compared with their non-gifted same-age-peers, they tend to obtain higher academic achievements (Gagné, 1993; Freeman, 1998) they have an excellent ability to solve new and complex problems (Klavir \& Gorodetsky, 2001), they possess special learning capabilities (Gorodetsky \& Klavir, 2003), remarkable creative thinking (Feldhusen, 1986) and high-order reasoning abilities (Shore \& Kanevsky, 1993). Despite the notion nowadays that a high IQ score is not the unique factor for determining giftedness (e.g. Tannenbaum, 1983), and despite broad agreement that intellectual giftedness is not the only type of giftedness (Gardner, 1983), most researchers agree that intellectually gifted pupils are still a special group within the educational system with special abilities, potential, and needs (Milgram, 1989; Gross, 2000).

\section{Why Should The Educational System Handle Gifted Pupils In A Special Way?}

The fulfillment of the relative excellence of gifted depends largely on the support and special attention they receive from the environment, including the educational system (Van Tassel-Baska, 2001). It is assumed that it is the responsibility of the school and governmental agencies to bring these children to their optimal achievement and usually this assumption is not questioned. But indeed, why should educational efforts be directed towards the gifted when, according to common notions, "they will excel with or without appropriate school programs" (Croft, 1999)? There are at least three reasons that justify such special efforts and investments: The first, which is expressed in the controversial essay by Hernstein \& Murray (1994), views high intelligence as an important national and international human resource and as a possible vehicle for the advancement of the society as a whole. From this point of view, effortful educational investments by the society for the benefit of gifted and talented children, is in fact also being made for the benefit of society itself (see also: Hunt, 1995; Reis, 1989). On the basis of a similar view, NATO-UNESCO organized and sponsored a special international meeting in 2002, in Budapest Hungary. The 
subject was: 'Science Education: Talent Recruitment and Public Understanding' (NATO-UNESCO, 2002). The meeting, which was attended by thirty-two representatives from the United States, Europe, and Israel, renowned scientists and prominent researchers in the field of education, framed a joint call to the leaders of various countries to formulate special programs to foster gifted and talented youth. This promising potential, according to the majority of speakers at the conference, is essential to the advancement of science, the economy, art, and culture of each and every country, hence special effort should be invested to foster it.

The second reason, which stems from the opposite direction, adopts the concept that the educational system is obligated to view each pupil as a unique individual with her/his own special characteristics, wishes and capabilities. Thus, educational investment has to be directed toward providing a suitable educational environment for the benefit of every 'different' child in the system: a learning-disabled pupil, a mentally retarded one, as well as a gifted child. In this context, gifted children as a special group of pupils within the educational system have their own rights to receive a suitable curriculum, appropriate assistance and differential attention to their special characteristics and needs (Kearney, 1993; Eyre, 2004). The uniqueness of every gifted pupil as an individual child, as well as the special characteristics and needs that she/he shares with other gifted pupils, as it appears in the professional literature, compel educators to view gifted pupils differentially and to provide them with suitable solutions (Milgram, 1989). Finally, the third reason argues that gifted children are liable to suffer from numerous problems and difficulties in the absence of a suitable educational environment. Croft (1999) for example, concludes that students most seriously affected by poor teaching in inclusive public schools were the gifted ones. Gallagher, et al., (1997) emphasize that frustration can be a dangerous outcome of the absence of appropriate cognitive challenges for gifted pupils. Other professional scholars in the field of gifted education (e.g., Van Tassel-Baska, 2001) include additional consequences such as loss of willingness to learn, absenteeism, development of disruptive behaviors, harboring hard feelings towards teachers and the entire school system, developing underachievement and withdrawal of learning habits. Gross (2000) emphasizes that these pupils are especially vulnerable and can thus suffer more than other pupils from numerous kinds of problems. Conversely, Hébert (2000) found that receiving appropriate special programs in their regular classes, getting special attention from meaningful adults and being involved in special extracurricular activities, have a positive correlation with inner motivation and learning aspirations as well as with a strong belief of the intellectually gifted pupils in themselves.

\section{Do Professional Experts Have Sufficient Practical Recommendations On How The Educational System Should Handle Gifted Pupils?}

Numerous types of professional recommendations can be found in the educational literature for choosing an appropriate policy toward gifted pupils. From special schools, where the gifted study together with other gifted pupils in programs outside the regular schools, through many and varied nurturing programs in their 'natural' heterogeneous class such as enrichment (e.g., Milgram, 1989; Van Tassel-Baska, 2001) and acceleration (e.g., Van Tassel-Baska, 1992). Laurie Croft (1999), principal of The Center for Gifted Education and Talent Development at the University of Iowa, claims that according to empirical research, combinations of enrichment and acceleration lead to successful learning. As the majority of these children spend most of their time in regular educational settings (Milgram, 1989; Parke 1992), it is to be expected that their teachers would recognize them as a group with special needs within the heterogeneous class. Thus, it is not surprising that almost every popular "Educational Psychology" book (for example: Eggen \& Kauchak, 1994; Gage \& Berliner, 1992; Woolfolk, 1995), the section that deals with exceptionalities in the heterogeneous class, includes special chapters about gifted children; their special characteristics and needs as well as appropriate methods (didactical and pedagogical) to gear teaching towards this population within inclusive classes. Numerous types of professional recommendations can also be found in specific educational literature that focuses on giftedness and gifted pupils' education. As previously mentioned, recommended strategies towards gifted pupils in their 'natural' heterogeneous class (e.g., Freeman, 1998; Rogers \& Span, 1993; Renzulli \& Reis, 2002) can be found here too.

Thus, gifted children can suffer from unique problems within the educational system, especially when they spend most of their school time in fully inclusive educational programs and when learning in 'regular' heterogeneous classes. Some of their problems may arise because of inappropriate attitudes of their teachers, teachers' lack of awareness to the needs of these pupils and lack of knowledge regarding professional 
recommendations in the field (Croft, 1999; Tannenbaum, 1983). Hence, many researchers recommend including gifted education as an integral part of the learning settings of pre-service and in-service teachers (e.g. Moon et al., 1999). An interesting possibility is to encourage teachers to talk to these gifted students. Ziv (1990) cites a school administrator in Israel who claims that one of the best ways to clarify what has been done and what needs to be done for gifted children is simply by asking them about their feelings, their problems and the ways in which teachers treat them and could help them. Such clarification can become an effective tool for in-service and pre-service teachers to gain professional knowledge about these issues. The present study adopted these recommendations. It addresses the issue of what pre-service teachers discovered by talking face to face with gifted pupils about their state and their needs, as they are perceived by the pupils themselves. Correspondingly, the present paper consists of two parts: (a) The information the pre-service teachers uncovered from their interviews with gifted pupils about the state of gifted pupils of different ages at school; and (b.) the reactions of the pre-service teachers to this information.

\section{METHOD}

During their teaching program, pre-service teachers participated in a course concerning teaching in the heterogeneous classroom. As an introduction to the issue of 'gifted children', the pre-service teachers were given an assignment: (1) to interview gifted children (identified as gifted by the Ministry of Education, according to IQ level) in their own classes or schools, about their situation in the heterogeneous class or school. (2) To write a personal reflection about what they learned from these interviews. These data provided the basis for the study of the unique needs of the 'gifted children' and the responses of pre-service teachers to these issues. The present study is based on the analysis of these collective results. On the one hand, it presents the picture obtained by the pre-service teachers from analysis of their interviews (Part I). On the other, the study presents the analysis of the pre-service teachers' responses to Part II of the assignment.

Participants: Gifted pupils: The interviewed pupils were of different ages and were classified accordingly into age groups. Group 1: elementary school $\left(3^{\text {rd }}-6^{\text {th }}\right.$ grade) $n=16$; Group 2: junior-high $\left(7^{\text {th }}-9^{\text {th }}\right.$ grade) $n=30$; Group 3 : high school $\left(10^{\text {th }}-12^{\text {th }}\right.$ grade) $\mathrm{n}=27$; Group 4 : young adults (19-22 years old, and close to finishing high school) $\mathrm{n}=15$. All the participants were identified as gifted children by the Ministry of Education (IQ being above 131). Since the interviewed pupils came from different geographic regions in Israel, this sample can be considered as a random sampling that represents the entire population of gifted pupils in Israel. Pre-service teachers: $n=88$. Being in their second year of study. These pre-service teachers teach two days per week in schools in their neighborhood as part of their training.

Research tool: The research tool was a semi-open interview in which the gifted pupils were asked to address three issues: (a) Describe your situation regarding your studies in the classroom and the school. (b) Describe your social situation. (c) Describe how your teachers treat you. The issues were intentionally presented in general terms to avoid directing the pupils to providing specific answers. However, since the questions were general in nature, the inservice beginner teachers occasionally added some concrete questions during the interviews. Thus, for example, when the pupils responded to the first question with an answer such as "Everything's all right", or alternatively, "I hate studying", some of the interviewers added questions such as, "Why do you say that your situation is good/terrible?" or "What do you mean when you say...?" "Can you give examples?" The same applied to the other questions.

Method of analysis: The responses of the gifted pupils to the three interview questions provided the data for the analysis. The analysis was comprised of two consecutive steps and was done jointly by two analyzers (the researcher and a research-assistant). Every decision was accepted only after full agreement was achieved between the two analyzers.

The first step: The analyzers read all the answers several times and made an initial content analysis towards a possible classification of the data. This was done separately for Parts I and II as follows:

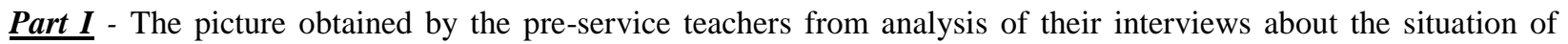
gifted pupils in the heterogeneous classes: four main issues seemed to emerge: (1) Learning environment: 
suitability of content, pedagogy and didactics to pupils' needs, capabilities and expectations, (2) Social status: the interactions of the gifted pupils with their peers and classmates, (3) Interactions with teachers: the attitudes and behaviors of the teachers towards the gifted pupils, and (4) Reactions and feelings of the gifted pupils at school.

$\underline{\text { Part II }}$ - The picture obtained from analyzing the personal reflections of the pre-service teachers about what they learned from these interviews. One main issue seemed to emerge: (5) The professional knowledge the pre-service teachers gained from the interviews - its levels and nature.

The second step: The two analyzers reread the protocols together and decided on the categories and sub-categories regarding each of these five issues. An attempt was made to identify similar and/or repeated themes. Initially, the themes were general, but following several reading-cycles more refined and specific categories and sub-categories were defined for the five issues.

The maintained sub-categories were assigned ordinal and/or nominal levels. This depended on the nature of the reports of the pupils and the pre-service students. If the protocols showed that different pupils mentioned different levels of severity regarding a problem (e.g., boredom), a hierarchy of levels of severity of this issue was established, scaled and graded (e.g., 0 was assigned when no boredom was mentioned, and 3 for a case that described boredom as a very prolonged and severe problem during schooling). A nominal categorization was carried out for cases that related to different aspects of the issue. For example, different sources (reasons) for boredom were expressed in the interviews. These were classified as sub-categories of boredom and assigned four nominal values (aspects): (1) boredom stemming from fast understanding; (2) boredom stemming from prior knowledge of the material; (3) boredom stemming from lack of intellectual challenges; (4) boredom stemming from being taught subjects not included in their fields of interest.

The established organization of the categories and sub-categories (levels and/or aspects) within the five issues (four of Part I and one of Part II) is described in Table 1.

\section{Categories and sub-categories defined for the analysis}

\section{Part I}

\section{- Issue (1) - Learning Environment: Boredom}

(1A) Levels of Boredom - The level of boredom expressed by each gifted pupil on a four-level scale, from 3 assigned to cases of boredom in all lessons: "My biggest problem is that I get to school and start getting bored right off. Sometimes I can't even keep going and my whole body itches with boredom..." (A junior-high pupil)], to 0 - for cases in which boredom was not mentioned as a problem.

(1B) Reasons for Boredom - The aspects perceived by the gifted pupils as responsible for their feelings of boredom. The reasons stated by the gifted pupils were classified into four types: (1) boredom stemming from fast understanding; (2) boredom stemming from prior knowledge of the material; (3) boredom stemming from lack of intellectual challenges; (4) boredom stemming from being taught subjects not included in their fields of interest.

\section{- Issue (2) - Social status: self-perception of social status}

(2A) Levels of Social Status - Pupils' self-perception of their social status was categorized on a two-level scale, from 1 - when the gifted pupil described her/his social situation as problematic: "Last year the whole class ostracized me. I didn't have a single friend. They called me 'show-off' and all kinds of names. They were all on the outs with me. Maybe they were jealous that I'm successful and get 100s in all the subjects... It's a bit better this year. I am not really being ostracized but I can't say that I've got many girlfriends in the class" (An elementary school pupil)], to 0 - when the gifted pupil did not claim any social problems. 
(2B) Sources (reasons) for Social Problems - The reasons raised in the interviews were classified into two types: (1) External reasons - stemming from their classmates' behavior and feelings toward them: "In my opinion some of the pupils didn't dare get close to me because I appeared to them as an odd creature who was always studying... Despite my trying to get close to them they had reservations about me and didn't really accept me... In this case giftedness really bothered me." (A graduate). (2) Internal reasons - social problems that were perceived as stemming from their own difficulties in connecting to their classmates: "I have one friend in the class. The rest just don't interest me and we don't have a common language”. (An elementary school pupil).

\section{- Issue (3) - Interactions with Teachers: attitudes and behaviors of teachers towards the gifted pupils}

$\left(3 B_{1}\right)$ Supporting behaviors of the teachers - These were divided into two categories: $\left(3 \mathrm{~B}_{1}-1\right)$ and $\left(3 \mathrm{~B}_{1}-1\right)$ as follows:

$\left(3 B_{1}-1\right)$ In the scholastic field - Teachers' activities provided at school to prevent boredom and to accelerate fulfillment of pupils' potential were classified into two types: (1.1) Local solutions - provided sporadically by a small number of teachers: "I enjoy myself most of all with the biology teacher because she sometimes prepares additional explanation sheets for me and special experiments.” (A junior-high pupil). (1.2) Institutional solutions provided by the school and most of the teachers as part of an established approach: "In our school there are groups for outstanding pupils. I chose chess, mathematical thinking and art. It's great because three times a week we get out of lessons... If I start getting bored or finish all the teachers' assignments, I can go and work in art or to the chess corner to solve chess problems the teacher left us." (An elementary school pupil).

$\left(3 B_{1}-2\right)$ In the social field - Pupils' responses regarding the figures that help them to cope with social problems. These were classified into three types and one of these was assigned for each pupil: (2.1) Teachers: "When my girlfriends ostracized me, my homeroom teacher and the counselor helped me." (A junior-high pupil). (2.2) Parents: "My parents say that I should find my own way of coping because the jealousy of others over my grades will always be with me. Sometimes my Dad explains to me all kinds of ways of ignoring them ..." (An elementary school pupil). (2.3) Self-coping - When the gifted pupils state that they cope with these problems on their own, and/or when they state that no one is aware of their difficulties and/or helps them cope: "At one stage I simply stopped going to Beit Ariel (a weekly enrichment day for gifted pupils) and started playing soccer with the boys. When they saw I was just like them they became my friends. Today two of them are at university with me and we're still good friends... Today they really appreciate the achievements that used to be an excuse for teasing me..." (A graduate).

$\left(3 B_{2}\right)$ Inappropriate behaviors of the teachers - Teachers' inappropriate behaviors towards gifted pupils were defined: (1) Teachers' excessive demands from the gifted pupils ["It's obvious to my parents that I'll get 100 in every exam... and they (the teachers) also think I can answer every question. It upsets me... (A junior-high pupil)]. (2) Teachers' deliberate offensiveness refers to cases where the teacher appeared to be aware of pupils' giftedness and for that same reason treated them offensively (e.g., deliberate disregard, harassment and singling out, or expression of impatience and intolerance to the intellectual demands of gifted pupils.). For example: "The teachers give me permission to answer questions only when they see that other pupils aren't raising their hands...when I want to answer, they say, 'I know you know... but I want other pupils to answer... it causes me to get bored and makes me nervous..." (A high school pupil). "The English teacher gets angry at me because I finish the booklets very quickly...” (An elementary school pupil). “...There are teachers that get irritable when I ask questions, so I prefer to shut up..." (A high school pupil). (3) Teachers' unintentional inappropriate behavior - cases in which the teacher was unaware of the pupils' giftedness and special needs. These behaviors consist of unintentional disregard ["...In most cases they (the teachers) just didn't notice that I was bored and didn't devote any thought to it... It happened more in the lower classes but in high school as well... I'd go home stressed... I felt I was just wasting time and not learning anything..." (A graduate)]. A further example: "In junior-high we were three gifted children in the same class. We suffered from boredom but we were good kids who didn't make trouble for the teachers. So they [the teachers] thought that everything was fine with us and they could carry on teaching everybody and repeat things over and over without considering us..." [A high-school pupil] 


\section{- Issue (4) - Reactions and feelings of the gifted pupils at school: scholastic situation and behavioral reactions}

(4A) Scholastic situation - The scholastic situation of each gifted pupil was classified on a three-level scale, from 3 [in cases when the gifted pupils described themselves as excelling in all subjects: "My average grade on my report card is usually 100." (A junior-high pupil)], to 1 [when they claimed that they were not good students and/or encountered difficulties in all school subjects: "Today, when I'm studying engineering at the university and doing quite well, I think that my matriculation grades reflected a very poor scholastic state that stemmed from total boredom and lack of effort." (A graduate)].

Table 1: The categories and sub-categories (levels and/or aspects) within each of the five discussed issues

\begin{tabular}{|c|c|c|}
\hline \multirow{2}{*}{ Main issues } & \multicolumn{2}{|r|}{ Sub-categories } \\
\hline & A. Levels & B. Aspects \\
\hline \multicolumn{3}{|l|}{ part I. } \\
\hline $\begin{array}{l}\text { (1) Learning environment of the } \\
\text { gifted pupils: } \\
\text { Boredom }\end{array}$ & $\begin{array}{l}\text { (1A) A four-level scale: } \\
\underline{\text { From } 3} \text { (most severe) to } 0 \text { (least }\end{array}$ & $\begin{array}{l}\text { (1B) Four types of sources (reasons) for } \\
\text { boredom: } \\
\text { (1) Fast understanding } \\
\text { (2) Prior knowledge } \\
\text { (3) Lack of intellectual challenges } \\
\text { (4) Being taught subjects not included in their } \\
\text { fields of interest. }\end{array}$ \\
\hline $\begin{array}{l}\text { (2) Social status of the gifted } \\
\text { pupils: } \\
\text { Self-perception of social status }\end{array}$ & $\begin{array}{l}\text { (2A) A two-level scale: } \\
\text { From } 1 \text { (a problematic status) to } 0 \\
\text { (a non-problematic status) }\end{array}$ & $\begin{array}{l}\text { (2B) Two sources (reasons) for the social } \\
\text { problems: } \\
\text { (1) External reasons } \\
\text { (2) Internal reasons }\end{array}$ \\
\hline \multirow{2}{*}{$\begin{array}{l}\text { (3) Interactions of the gifted } \\
\text { pupils with teachers: } \\
\text { The attitudes and behaviors of } \\
\text { teachers towards their gifted } \\
\text { pupils. }\end{array}$} & & $\begin{array}{l}\text { (3B } B_{1} \text { Supporting behaviors of the teachers } \\
\text { (1) In the scholastic field } \\
\text { (1.1) Local solutions } \\
\text { (1.2) Institutional solutions } \\
\text { (2) In the social field } \\
\text { (2.1) Teachers help them } \\
\text { (2.2) Parents help them } \\
\text { (2.3) Self-coping by the pupil (not teachers or } \\
\text { parents) }\end{array}$ \\
\hline & & $\begin{array}{l}\left(3 B_{2}\right) \text { Inappropriate behaviors of the teachers } \\
\text { (1) Excessive demands } \\
\text { (2) Deliberate offensiveness } \\
\text { (3) Unintentional inappropriate behaviors }\end{array}$ \\
\hline $\begin{array}{l}\text { (4) The reactions and feelings of } \\
\text { the gifted pupils at school: } \\
\text { The scholastic situation and the } \\
\text { behavioral reactions }\end{array}$ & $\begin{array}{l}\text { (4A) Scholastic situation: } \\
\text { From } 3 \text { (the most excellent level) } \\
\text { to } 1 \text { (the least excellent level) }\end{array}$ & 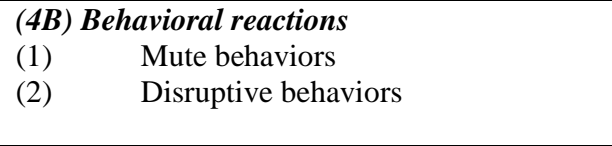 \\
\hline \multicolumn{3}{|l|}{ part II. } \\
\hline $\begin{array}{l}\text { (5) Profesional Knowledge } \\
\text { gained by pre-service teachers: } \\
\text { New professional knowledge }\end{array}$ & $\begin{array}{l}\text { (5A) Level of learning: } \\
\text { From } 3 \text { (Definitely gained new } \\
\text { professional knowledge to } 1 \text { (Did } \\
\text { not gain any new professional } \\
\text { knowledge) }\end{array}$ & $\begin{array}{l}\text { (5B) The nature of gained knowledge } \\
\text { (1) Insight into gifted pupils. } \\
\text { (2) Insight into themselves as teachers. }\end{array}$ \\
\hline
\end{tabular}

(4B) Behavioral situation - Pupils' behavior during lessons as a result of frustration, boredom, anger directed at the school and/or teachers, and social difficulties, were classified into two categories: (1) Mute behaviors (or "Withdrawal Responses" according to Whitmore, 1979) - cases in which the gifted pupils tried to cope with the above problems in a quiet manner not to attract attention, such as inattentiveness, surreptitious reading and/or drawing, "concealment of knowledge" by refraining from answering or asking questions to avoid envy or special attention of teachers and/or other pupils. For example: ["I sometimes bring a book from home and when I start 
getting bored I just read it under the desk." (A junior-high pupil). Another example: "I learned that in order to avoid confrontation with the teachers I had to keep quiet. I didn't ask questions and didn't correct mistakes... That way I avoided confrontation with the teachers." (A graduate). (2) Disruptive behaviors (or "Aggressive, Hostile Responses" according to Whitmore, 1979) - cases in which the gifted pupils react in an extrovert and disruptive manner, such as disruptiveness, being vociferously argumentative with teachers, excessive absenteeism, and nonpreparation of homework and class assignments. For example: * "A lot of times I prefer to stay home and work on my computer or play [an instrument] instead of going to school to get bored again. It happens quite often and my parents let me..." (An elementary school pupil). * "It's impossible to ask questions with the history teacher. Every time you ask questions she gets angry. Not just at me. At anyone who dares asks questions she thinks we are superfluous or when she's afraid she doesn't know the answers... At first it quite put me off. But this year I decided that it's quite a nice way of passing the time in her lessons: I always have something to ask and she's angry all the time and complains to my parents and the homeroom teacher that I'm disturbing her." (A high-school pupil).

\section{Part II}

\section{- Issue (5) - The professional knowledge the pre-service teachers gained from the interviews}

(5A) Levels of learning - Three hierarchical categories were identified: (3) Definitely gained new professional knowledge - the pre-service teachers encountered new facts about gifted pupils. In some cases this knowledge was so new to them that they were really surprised at the information they obtained, since it contradicted their expectations, their preconceptions of giftedness and/or their previous knowledge regarding the situation of gifted pupils in heterogeneous classes: "Before the interview I thought that gifted pupils don't have to tackle any problems in school... that only pupils with learning disabilities have problems... It has now become clear to me that these pupils also have problems... I didn't think about it in this way..." (Dina). (2) Gained additional knowledge although the pre-service teachers do not express surprise, they explain that they learned new and previously unknown aspects from the interviews. (1) Did not gain any new professional knowledge - the pre-service teachers reported that they did not learn anything new about giftedness or the situation of gifted pupils in the classroom from the interviews.

(5B) Professional knowledge gained by pre-service teachers - What did the pre-service teachers who gained knowledge (subcategories 1 and 2 in 5A above) learn from the interviews? The information obtained regarding this question was analyzed according to two aspects: (1) Insight into gifted pupils - in their reflections the pre-service teachers focus on insights reached as a result of the interviews regarding the characteristics of gifted pupils, their difficulties and hardships in the heterogeneous class. The reflections focus on different types of characteristics of gifted pupils, that emerged from the pupils' responses [ "...I learned a lot of new things from the interview with Arieh. I reached important conclusions about the special needs of gifted pupils... affective, cognitive and social..." (Yaron)]. (2) Insight into themselves as teachers - in their reflections the pre-service teachers focus on the insights reached as a result of the interviews regarding their own behaviors and attitudes towards gifted pupils: How they have behaved until now and what they should do from now on [ "...As a teacher I understood that although we want to advance pupils with learning difficulties by cooperation with good learners, we must check whether the former will absorb the latter... and pay more attention to their [the gifted pupils] social problems and not only their learning problems..." (Nira)]. In other words, whereas the focus of the pre-service teachers in aspect (1) above was on the gifted pupils, in aspect (2) their focus was on themselves as teachers.

\section{RESULTS}

\section{- Issue (1) - Learning Environment: Boredom}

1) Prevalence of the problem of boredom $\{1 \mathrm{~A}\}$ : 61 of the 88 interviewees $(69 \%)$ raised the problem of boredom and referred to it (albeit they were not directly asked about it). The $\mathrm{X}^{2}$ test for independent samples (the four age groups) showed that most of the pupils in each group (between $81 \%$ and $94 \%$ ) described boredom as a problem that troubled them to a certain degree (from 1 to 3 ). There was no significant variance between the groups (see Table 2). 
2) Degree of boredom severity as perceived by the gifted pupils $\{1 \mathrm{~A}\}$ : An ANOVA One-Way Analysis (dependent variable: degree of boredom severity between 0 and 3; independent variable: the four age groups) showed a similar degree of boredom severity (average degree of severity of 1.94, 2.24, 2.19, 2.42 in the elementary, junior-high, high school, and graduate groups respectively) with no significant variance between them (see Table 3 ). The maximal degree of boredom severity in each of the groups was found to be 3 (the problem is severe and typifies all lessons), and the minimal degree was 0 (no boredom problem at all). A Post-Hoc LSD test showed no significant variance between the groups. In other words, the average degree of severity (ranging around the second degree of boredom: a great deal of boredom in most lessons) similarly characterizes all four groups.

3) The reasons for boredom as perceived by the gifted pupils $\{1 \mathrm{~B}\}$ : Analysis of the results indicated that 61 gifted pupils who raised the problem of boredom used more than one reason to explain it. Thus, a total of 123 responses was obtained. The $\mathrm{X}^{2}$ test for independent samples (the four types of reasons) showed no significant variance in the prevalence of reasons stated by the four age groups. The most prevalent reason was: "prior knowledge" (37\% of the total responses), followed by "fast understanding" (28\%), "lack of intellectual challenges" (23\%), and "lack of interest in the subjects being taught" $(20 \%)$, due to being taught subjects not included in their fields of interest (See Table 4).

\section{- Issue (2) - Social Status: Self-Perception Of Social Status}

1) Prevalence of social problems $\{2 \mathrm{~A}\}$ : $72 \%$ of the interviewees were found to have social problems. The $X^{2}$ test for independent samples (the four age groups) showed no significant variance between the groups (see Table 5). The majority of pupils in each age group suffered from social problems: $88 \%$ of the gifted pupils in elementary school, $63 \%$ in junior-high, $78 \%$ in high school, and $60 \%$ of the graduates.

2) Degree of severity of the social problem $\{2 \mathrm{~A}\}$ : An ANOVA One-Way Analysis (dependent variable: degree of severity of social problems, independent variable: the four groups) showed a similar level of the severity of social problems, with no significant variance between the age groups (see Table 6). These values indicate that the average degree of severity of social problems in all groups is closer to ' 1 ' (there are social problems) than to ' 0 ' (there are no such problems).

3) The sources (reasons) for social problems $\{2 \mathrm{~B}\}$ : Only $63 \%$ of the gifted pupils provided reasons for their social problems. Altogether there were 70 responses that were classified into two types. The $\mathrm{X}^{2}$ test for independent samples (the four age groups) showed no significant variance in distribution of the two types of reasons for social problems in the four groups (see Table 7). The first type was associated with their friends' difficulties in accepting them, connecting to them or forming a common language (69\%), the second type related to the gifted pupils' choice to isolate and/or distance themselves from their friends due to difficulties in finding a common language or other similar reasons.

\section{- Issue (3) - Interactions With Teachers: Attitudes And Behaviors Of Teachers Towards Their Gifted Pupils} $\left\{3 B_{2}\right\}$.

Two central kinds of teachers' behaviors were detected in the protocols: (a) supportive $\left\{3 \mathrm{~B}_{1}\right\}$; (b) offensive

\section{a) Supportive behaviors of teachers}

1) In the scholastic field (Assistance in overcoming boredom and associated learning problems) $\left\{3 \mathrm{~B}_{1}-1\right\}$ : Only 61 interviewees raised this issue and provided 94 types of responses. For example: Acceleration through providing textbooks of a higher level, worksheets on a higher level); recruiting the gifted pupil to help classmates; enrichment outside the classroom employing special activities (such as work in the laboratory, the library, preparing a newspaper in the computer lab). The behaviors indicated were either local $\left\{3 \mathrm{~B}_{1}-1-1.1\right\}$, i.e., sporadic and local solutions that were provided by a small number of teachers $(71 \%)$ or institutional $\left\{3 \mathrm{~B}_{1}-1-1.1\right\}(29 \%)$, namely the result of the school's initiative and as such are implemented on a regular basis by a large number of teachers as a 
norm in the heterogeneous classroom and/or school. The $\mathrm{X}^{2}$ test for independent samples (the four age groups) showed no variance in the prevalence of either of these activities: institutional and local (see Table 8).

2) Assistance in overcoming social problems $\left\{3 \mathrm{~B}_{1}-2\right\}$ : Of the 63 interviewees who described social status as problematic, the majority (60\%) stated that they received no assistance at all, $16 \%$ stated that the teachers help them to cope with social problems, $24 \%$ stated that their parents assisted them. The $\mathrm{X}^{2}$ test for independent samples (the four age groups) showed no variance in the ratio between the three types of assistance. In each age group, the percentage of cases in which gifted pupils stated that they receive assistance from the teachers was lower than the percentage of cases that acknowledged the help of their parents in this respect, and from the percentage of cases in which they stated that they receive no assistance (see Table 9).

\section{b) Offensive behaviors of teachers}

Gifted pupils tended to complain that their teachers offend them and treat them inappropriately $(71 \%$ of the 88 interviewees), with the inappropriate behaviors of the teachers being associated with the giftedness of the pupils. The $\mathrm{X}^{2}$ test for independent samples (the four age groups) showed no significant variance between the groups (see Table 10). However, the $\mathrm{Z}$ test for proportions showed that the prevalence of this kind of complaint among the elementary school gifted pupils was significantly lower $(44 \%)$ than that of junior-high pupils $(80 \%)$ [ $\mathrm{p}=0.0006$, $\mathrm{Z}=2.50]$, or of the high school pupils $(74 \%)[\mathrm{p}=0.02, \mathrm{Z}=1.99]$, or the graduates $(73 \%)[\mathrm{p}=0.05 ; \mathrm{Z}=1.67]$. However, no significant variance was found among the three older groups. These results indicate that the elementary school pupils report significantly fewer inappropriate behaviors of teachers than the older pupils.

Teachers' inappropriate behaviors as reported by the interviewees included three types. Altogether there were 101 responses. The $\mathrm{X}^{2}$ test for independent samples (the four age groups) showed no significant variance in prevalence of the three types of inappropriate behaviors by teachers toward the gifted pupils in the four age groups (see Table 11).

\begin{tabular}{|c|c|c|c|c|c|c|c|c|c|c|}
\hline & \multicolumn{2}{|c|}{$\begin{array}{c}\text { Elementary } \\
\text { school }\end{array}$} & \multicolumn{2}{|c|}{ Junior-high } & \multicolumn{2}{|c|}{ High-school } & \multicolumn{2}{|c|}{ Graduates } & \multicolumn{2}{|c|}{ Total no. } \\
\hline & ${ }^{1} \mathrm{n}$ & ${ }^{2}$ perc & $\mathrm{n}$ & perc & $\mathrm{n}$ & perc & $\mathrm{n}$ & perc & $\mathrm{n}$ & perc \\
\hline Table 2: & \multicolumn{10}{|c|}{$\begin{array}{l}\text { Prevalence of cases in which the gifted pupils stated the existence of boredom (severity on } \\
\text { a scale of } 1-3 \text { ) or its absence (severity } 0)^{\mathrm{a}}\end{array}$} \\
\hline Problem of boredom & 13 & $81 \%$ & 15 & $88 \%$ & 15 & $95 \%$ & 11 & $92 \%$ & 54 & $89 \%$ \\
\hline No problem of boredom & 3 & $19 \%$ & 2 & $12 \%$ & 1 & $5 \%$ & 1 & 8 & 7 & 11 \\
\hline Total No. of answers & 16 & $100 \%$ & 17 & $100 \%$ & 16 & $100 \%$ & 12 & $100 \%$ & 61 & $100 \%$ \\
\hline Table 5: & \multicolumn{10}{|c|}{$\begin{array}{l}\text { Prevalence of cases in which the gifted pupils stated the existence of a social problem or } \\
\text { its absence }\end{array}$} \\
\hline Social problem & 14 & $88 \%$ & 19 & $63 \%$ & 21 & $78 \%$ & 9 & $60 \%$ & 63 & $72 \%$ \\
\hline No social problem & 2 & $12 \%$ & 11 & $37 \%$ & 6 & $22 \%$ & 6 & $40 \%$ & 25 & $28 \%$ \\
\hline Total No. of answers & 16 & $100 \%$ & 30 & $100 \%$ & 27 & $100 \%$ & 15 & $100 \%$ & 88 & $100 \%$ \\
\hline Table 8: & \multicolumn{10}{|c|}{$\begin{array}{l}\text { Prevalence of cases in which the gifted pupils stated that attempts are made to provide } \\
\text { local/institutional solutions to their problem of boredom }\end{array}$} \\
\hline $\begin{array}{l}\text { Local and sporadic } \\
\text { solutions }\end{array}$ & 10 & $67 \%$ & 13 & $77 \%$ & 11 & $65 \%$ & 9 & $75 \%$ & 43 & $71 \%$ \\
\hline Institutional solutions & 5 & $33 \%$ & 4 & $23 \%$ & 6 & $35 \%$ & 3 & $25 \%$ & 18 & $29 \%$ \\
\hline Total No. of answers & 15 & $100 \%$ & 17 & $100 \%$ & 17 & $100 \%$ & 12 & $100 \%$ & 61 & $100 \%$ \\
\hline Table 9: & \multicolumn{10}{|c|}{$\begin{array}{l}\text { Prevalence of cases in which the gifted pupils stated that attempts are made by } \\
\text { parents/teachers/no one to help them cope with their social problems }{ }^{\text {a }}\end{array}$} \\
\hline Help from teachers & 3 & $20 \%$ & 3 & $17 \%$ & 3 & $15 \%$ & 1 & $10 \%$ & 10 & $16 \%$ \\
\hline Help from parents & 4 & $27 \%$ & 4 & $22 \%$ & 5 & $25 \%$ & 2 & $20 \%$ & 15 & $24 \%$ \\
\hline No help & 8 & $53 \%$ & 11 & $61 \%$ & 12 & $60 \%$ & 7 & $70 \%$ & 38 & $60 \%$ \\
\hline Total No. of answers & 15 & $100 \%$ & 18 & $100 \%$ & 20 & $100 \%$ & 10 & $100 \%$ & 63 & $100 \%$ \\
\hline
\end{tabular}




\begin{tabular}{|c|c|c|c|c|c|c|c|c|c|c|}
\hline Table 10: & \multicolumn{10}{|c|}{$\begin{array}{l}\text { Prevalence of cases in which the gifted pupils describe/do not describe inappropriate } \\
\text { behaviors by teachers towards them }{ }^{\text {a }}\end{array}$} \\
\hline $\begin{array}{l}\text { Do not describe } \\
\text { inappropriate behaviors by } \\
\text { teachers }\end{array}$ & 9 & $56 \%$ & 6 & $20 \%$ & 7 & $26 \%$ & 4 & $27 \%$ & 26 & $29 \%$ \\
\hline $\begin{array}{l}\text { Describe inappropriate } \\
\text { behaviors by teachers }\end{array}$ & 7 & $44 \%$ & 24 & $80 \%$ & 20 & $74 \%$ & 11 & $73 \%$ & 62 & $71 \%$ \\
\hline Total No. of answers & 16 & $100 \%$ & 30 & $100 \%$ & 27 & $100 \%$ & 15 & $100 \%$ & 88 & $100 \%$ \\
\hline Table 13: & \multicolumn{10}{|c|}{ Prevalence of the three types of behavioral functioning of gifted pupils ${ }^{b}$} \\
\hline$\overline{\text { Mute behaviors }}$ & 10 & $70 \%$ & 11 & $41 \%$ & 2 & $12 \%$ & 5 & $35 \%$ & 28 & $38 \%$ \\
\hline Disruptive behaviors & 2 & $15 \%$ & 10 & $37 \%$ & 8 & $44 \%$ & 4 & $30 \%$ & 24 & $33 \%$ \\
\hline $\begin{array}{l}\text { Mute and disruptive } \\
\text { behaviors }\end{array}$ & 2 & $15 \%$ & 6 & $22 \%$ & 8 & $44 \%$ & 5 & $35 \%$ & 21 & $29 \%$ \\
\hline Total No. of answers & 14 & $100 \%$ & 27 & $100 \%$ & 18 & $100 \%$ & 14 & $100 \%$ & 73 & $100 \%$ \\
\hline
\end{tabular}

${ }^{1}$ No. of gifted pupils

${ }^{2}$ Percentage of column.

${ }^{3}$ Results of $X^{2}$ tests: ${ }^{a}$ No significant variance was found between the groups in the following tables: Table 2, 5, 8, 9, 10. b Significant variance was found between the groups in Table 13: $\left(\mathrm{X}^{2}=13.16\right.$ d.f. $\left.=6 \mathrm{p}=0.04\right)$.

\begin{tabular}{|c|c|c|c|c|c|c|c|c|c|c|c|c|c|c|}
\hline & \multicolumn{2}{|c|}{ Elementary school } & \multicolumn{3}{|c|}{ Junior-high } & \multicolumn{3}{|c|}{ High-school } & \multicolumn{3}{|c|}{ Graduates } & \multicolumn{3}{|c|}{ Total no. } \\
\hline & ${ }^{1} \mathrm{n} \quad s d$ & ${ }^{2} \mathbf{M}$ & $\mathrm{n}$ & $s d$ & $\mathbf{M}$ & $\mathrm{n}$ & $s d$ & $\mathbf{M}$ & $\mathrm{n}$ & $s d$ & $\mathbf{M}$ & $\mathrm{n}$ & sd & $\mathbf{M}$ \\
\hline \multicolumn{15}{|c|}{ Degree of boredom severity as perceived by the gifted pupils ${ }^{\mathrm{a}}$} \\
\hline & $16 \quad 1.12$ & 1.94 & 17 & 1.09 & 2.24 & 16 & 0.91 & 2.19 & 12 & 0.90 & 2.42 & 61 & 1.01 & 2.18 \\
\hline \multirow[t]{2}{*}{ Table 6: } & \multicolumn{14}{|c|}{ Degree of social problem severity as perceived by the gifted pupils ${ }^{\text {a }}$} \\
\hline & $16 \quad 0.34$ & 0.88 & 30 & 0.49 & 0.63 & 27 & 0.42 & 0.78 & 15 & 0.51 & $\mathbf{0 . 6 0}$ & 88 & 0.45 & 0.72 \\
\hline \multicolumn{15}{|c|}{ s of the gifted pupils as perceived by them ${ }^{b}$} \\
\hline & $15 \quad 0.00$ & 3.00 & 14 & 0.27 & 2.93 & 25 & 0.50 & 2.60 & 10 & 0.82 & 2.30 & 64 & 0.52 & 2.92 \\
\hline
\end{tabular}

${ }^{1}$ No. of gifted pupils.

${ }^{2}$ Average score: Table 3: Average severity of boredom (on a scale of 0-3). Table 6: Average severity of social problem (on a scale of 0-1). Table 12: Average achievements (on a scale of 1-3).

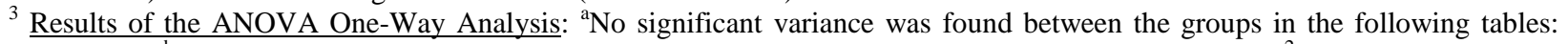

Table 3, 6. ${ }^{\mathrm{b}}$ Significant variance was found between the groups in Table 12: $\left[\mathrm{F}(3,63)=3.91 \mathrm{p}=0.001 \square_{\mathrm{p}}{ }^{2}=0.23\right]$.

\begin{tabular}{|c|c|c|c|c|c|c|c|c|c|c|}
\hline & \multicolumn{2}{|c|}{$\begin{array}{l}\text { Elementary } \\
\text { school }\end{array}$} & \multicolumn{2}{|c|}{ Junior-high } & \multicolumn{2}{|c|}{ High-school } & \multicolumn{2}{|c|}{ Graduates } & \multicolumn{2}{|c|}{ Total no. } \\
\hline & ${ }^{1} \mathrm{n}$ & ${ }^{2}$ perc & $\mathrm{n}$ & perc & $\mathrm{n}$ & perc & $\mathrm{n}$ & perc & $\mathrm{n}$ & perc \\
\hline Table 4: & \multicolumn{10}{|c|}{ Distribution of types of reasons for boredom described by the gifted pupils ${ }^{\mathrm{a}}$} \\
\hline Rapid understanding & 7 & $23 \%$ & 13 & $38 \%$ & 9 & $28 \%$ & 5 & $20 \%$ & 34 & $28 \%$ \\
\hline $\begin{array}{l}\text { Lack of intellectual } \\
\text { challenges }\end{array}$ & 11 & $37 \%$ & 14 & $40 \%$ & 13 & $39 \%$ & 8 & $32 \%$ & 46 & $37 \%$ \\
\hline Prior knowledge & 7 & $23 \%$ & 4 & $11 \%$ & 6 & $18 \%$ & 6 & $24 \%$ & 23 & $19 \%$ \\
\hline $\begin{array}{l}\text { Subjects taught are not in } \\
\text { their fields of interest }\end{array}$ & 5 & $17 \%$ & 4 & $11 \%$ & 5 & $15 \%$ & 6 & $24 \%$ & 20 & $16 \%$ \\
\hline Total No. of answers & 30 & $100 \%$ & 35 & $100 \%$ & 33 & $100 \%$ & 25 & $100 \%$ & 123 & $100 \%$ \\
\hline
\end{tabular}




\begin{tabular}{|c|c|c|c|c|c|c|c|c|c|c|}
\hline \multirow{2}{*}{$\begin{array}{l}\text { Table 7: } \\
\text { Difficulties of classmates } \\
\text { to accept them (external } \\
\text { reasons) }\end{array}$} & \multicolumn{10}{|c|}{ Distribution of types of reasons for social problems described by the gifted pupils ${ }^{\mathrm{a}}$} \\
\hline & 14 & $74 \%$ & 13 & $57 \%$ & 15 & $83 \%$ & 6 & $60 \%$ & 48 & $69 \%$ \\
\hline $\begin{array}{l}\text { Their own difficulties in } \\
\text { accepting classmates } \\
\text { (internal reasons) }\end{array}$ & 5 & $26 \%$ & 10 & $43 \%$ & 3 & $17 \%$ & 4 & $40 \%$ & 22 & $31 \%$ \\
\hline Total No. of answers & 19 & $100 \%$ & 23 & $100 \%$ & 18 & $100 \%$ & 10 & $100 \%$ & 70 & $100 \%$ \\
\hline \multicolumn{11}{|c|}{ Table 11: $\quad$ Distribution of the three types of offensive behaviors by teachers ${ }^{\mathrm{a}}$} \\
\hline $\begin{array}{l}\text { Excessive expectations and } \\
\text { demands }\end{array}$ & 5 & $25 \%$ & 7 & $21 \%$ & 9 & $33 \%$ & 4 & $19 \%$ & 25 & $25 \%$ \\
\hline Deliberate offensiveness & 6 & $30 \%$ & 12 & $36 \%$ & 10 & $37 \%$ & 8 & $38 \%$ & 36 & $37 \%$ \\
\hline $\begin{array}{l}\text { Unintentional } \\
\text { offensiveness }\end{array}$ & 9 & $45 \%$ & 14 & $43 \%$ & 8 & $30 \%$ & 9 & $43 \%$ & 40 & $38 \%$ \\
\hline Total No. of answers & 20 & $100 \%$ & 33 & $100 \%$ & 27 & $100 \%$ & 21 & $100 \%$ & 101 & $100 \%$ \\
\hline
\end{tabular}

No. of gifted pupils

${ }^{2}$ Percentage of column.

${ }^{3}$ Results of $\mathrm{X}^{2}$ tests: ${ }^{\mathrm{a}}$ No significant variance was found between the groups in the following tables: Table 4, 7, 11 .

\section{- Issue (4) - Reactions And Feelings Of The Gifted Pupils At School: Scholastic Situation And Behavioral Reactions}

Two major aspects seem to agitate the interviewees regarding their schooling: (a) scholastic functioning $\{4 \mathrm{~A}\}$ (b) behavioral functioning $\{4 \mathrm{~B}\}$.

\section{a) Scholastic functioning}

An ANOVA One-Way Analysis (dependent variable: scholastic situation between 1 and 3; independent variable: the four age groups) showed a significant variance between the groups with scores of 3.0, 2.93, 2.60, 2.30 in the elementary, junior-high, high school, and graduate groups respectively (see Table 12). In other words, the older the gifted pupils, the lower their evaluation of their scholastic situation and functioning. The values for pupils' scholastic situation drop with the age groups (from 3 to 2.30), whereas the standard deviation increases (being 0; 0.27; 0.50; and 0.82 for elementary, junior-high, high and graduates respectively). The results indicate that pupils' scholastic situation still ranges between 2 and 3 (average score), indicating that they are very good students although there is a decline as they grow older.

\section{b) Behavioral functioning}

Three categories were classified regarding pupils' behaviors: (1) Mute behaviors \{4B-1\}. (2) Disruptive behaviors $\{4 \mathrm{~B}-2\}$. (3) Behavioral functioning that can be defined as both mute and disruptive behaviors. A $\mathrm{X}^{2}$ test for independent samples (the four age groups) showed a significant variance in pupils' behavioral functioning in all four groups $\left(\mathrm{X}^{2}=13.16\right.$; d.f. $\left.=6 ; \mathrm{p}=0.04\right)$ (see Table 13). The ratio between the percentage of mute and disruptive reactions is approximately 4:1 respectively in elementary school, and changes in the opposite direction with age. For the junior-high gifted pupils it is 1:1, for the high school pupils $1: 4$ (11\% mute behaviors and 44 disruptive behaviors). Among the graduates, the situation appears somewhat more balanced with a similar distribution of the three types of behaviors. 


\section{- Issue (5) - Professional Knowledge Gained By Pre-Service Teachers:}

\section{a) Level of learning:}

The $\mathrm{X}^{2}$ nonparametric test showed a significant variance in prevalence between the three types of responses: Definitely gained new professional knowledge, gained additional knowledge, did not gain any new professional knowledge $\left(X^{2}=15.77\right.$ d.f. $\left.=2 \mathrm{p}=0.00\right)$ (See, graph 1). In other words, almost half the pre-service teachers $(47 \%)$ reported in their reflections that they gained additional information that was previously unknown to them about the situation of gifted pupils and their needs. About one-third of them (31\%) definitely gained new professional knowledge, and were sometimes even surprised. In other words, what they were told was previously unknown to them, and sometimes unexpected, or even contradicted their expectations, their previously held perceptions of giftedness and/or their previous knowledge about the situation of gifted pupils in heterogeneous classrooms. Only $13 \%$ of the pre-service teachers reported that they did not learn anything new from the interviews. ( $9 \%$ of the pre-service teachers did not address this matter in their reflections).

\section{b) What did they learn from the interviews?}

The pre-service teachers' responses were classified into three groups according to the insights they reached as a result of the interviews: (1) Pre-service teachers who in their reflections focused on their insights regarding characteristics of the gifted pupils. (2) Pre-service teachers who in their reflections focused on their insights regarding themselves as teachers. (3) Pre-service teachers who in their reflections focused on both types of insight. The $\mathrm{X}^{2}$ nonparametric test showed no significant variance in the percentages of pre-service teachers in each of the groups. Namely, following the interviews with the gifted pupils, about one-third of the pre-service teachers reached insights that gifted pupils have special needs and unique problems and difficulties. About one-third of the preservice teachers reached insights regarding their own behavior and their desired behavior as teachers of gifted pupils in heterogeneous classrooms. About one-third of the pre-service teachers reached both types of insight (see graph 2).

\section{DISCUSSION}

The present research attempted to enable pre-service teachers to discover different aspects of gifted pupils' life within the heterogeneous class. The purpose was to acquaint these novice teachers with this special group of pupils who in spite of being considered by the professional community as exceptional pupils do not in fact receive sufficient attention in the heterogeneous classes. Therefore, the study successively presents the picture obtained by the pre-service teachers from analysis of their interviews (Part I) including 4 main issues that emerged from the interviews, while the 2 main issues relating to the responses of the pre-service teachers to this picture (Part II) will be discussed jointly.

\section{$\underline{\text { Part I }}$}

(1) Learning environment: (a) about $2 / 3$ of the interviewees in the study express dissatisfaction with the taught content and describe it as a "boring" situation. No significant variance was found between the four age groups. (b) The reasons for their dissatisfaction are associated with the content being incongruent with their needs, standards, fields of interest, and their learning processes. A similar picture emerges in all four groups. (c) The average level of boredom and lack of interest in both content and learning in each of the groups was found to be around 2 (on a scale of 0 "not boring at all" to 3 "very boring"). This result is an indication that the gifted pupils do not find sufficient challenges to stimulate their curiosity and needs in the classroom.

(2) Social status: (a) About $3 / 4$ of the interviewees state that they suffer or suffered (in retrospect) from social problems. They experience bullying and ostracism, are isolated by their peers, are not invited to take part in social activities and do not make friends with their classmates. (b) In $2 / 3$ of the cases, the gifted pupils perceive this situation as stemming from the difficulties of their classmates to accept them, connecting to them, form a common language and understand them. This probably results from different languages, different fields of interest, and the high achievements of the gifted pupils being a source for envy and dispute. However, in about a $1 / 3$ of the cases, it is 
the choice of the gifted pupils to isolate and distance themselves from their classmates due to the difficulties of finding a common language or developing feelings of closeness and real friendship. (c) The average score reflecting the severity of social problems is similar for all age groups.

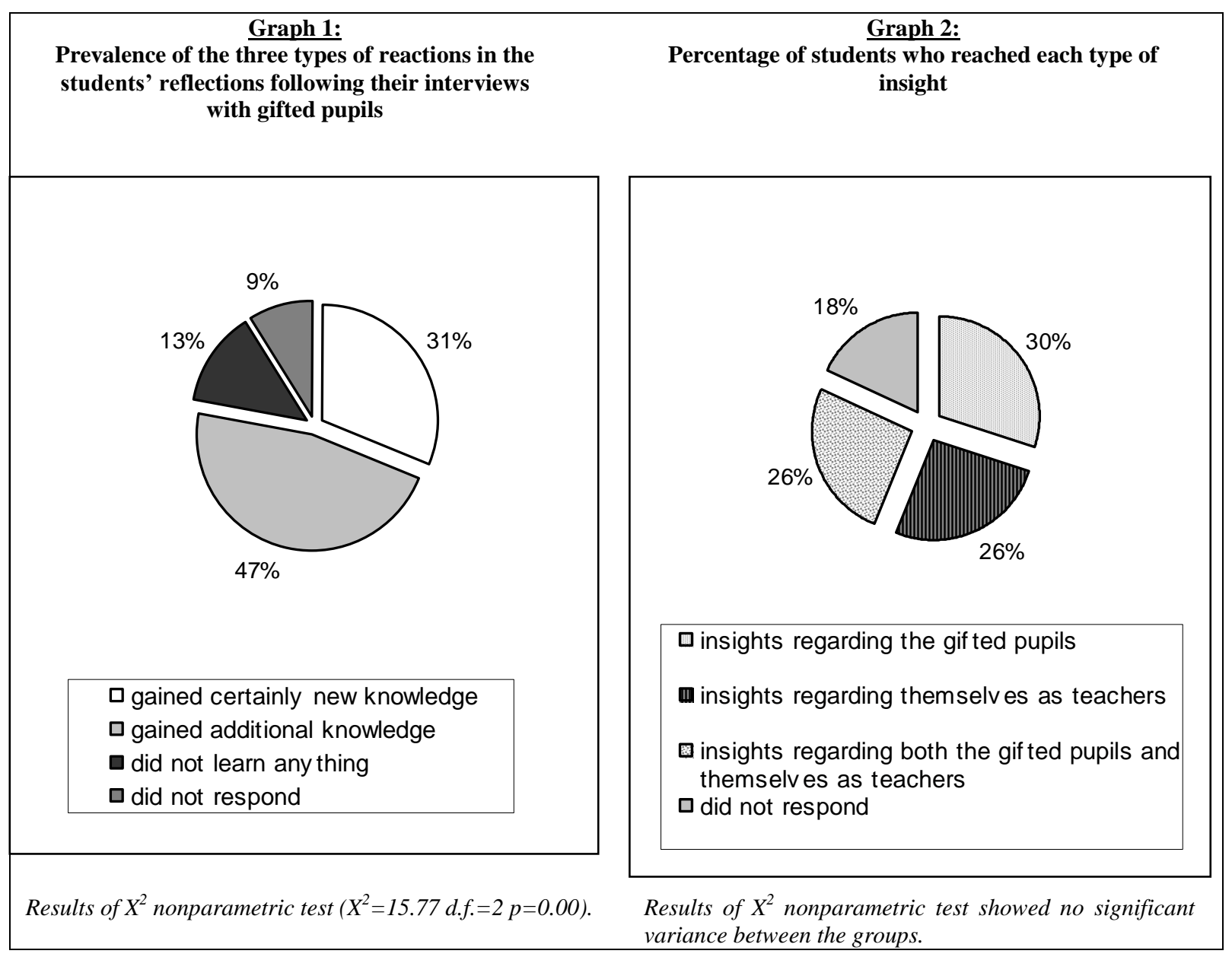

(3) The attitudes and behaviors of their teachers towards them: (a) Most of the gifted pupils stated that attempts are made at school to help them overcome their boredom and dissatisfaction with school. However, in $71 \%$ of the cases this is a sporadic effort undertaken by only a small number of teachers. (b) Help in solving social problems is provided by teachers in only $16 \%$ of the cases. $60 \%$ of them receive no help: neither from teachers, nor parents, nor anyone else. (c) The majority of the gifted pupils (71\%) stated that some teachers behave offensively and treat them inappropriately. There is no variance in this kind of behavior among the four age groups. As reported, this teachers' behavior stems from the unique characteristics of the gifted pupils. The following types of teacher behaviors were found: (1) Excessive expectations and demands for higher achievements (Lee \& Smith, 1993). Excessive pressure in this direction is liable to lead to opposite results (Freeman, 2001; Buescher \& Higham, 1990). (2) Deliberate offensiveness by teachers towards gifted pupils: Deliberate disregard, stemming from fear that the gifted pupils may gain dominance in the classroom and suppress the roles of the rest of the pupils in the classroom, or from fear of digressing from the planned lesson. Harassment and singling out gifted pupils due to fast completion of assignments, demonstration of boredom, or their 'wisecrack' answers. Expressing impatience and intolerance toward the "intellectual demands" of gifted pupils. The present study substantiates the findings that the very characteristics that can constitute a springboard for nurturing the excellence of gifted pupils (Feldhusen, 1996), constitute a source of irritation to teachers resulting in their offensive attitudes towards gifted pupils. The teachers 
do not nurture qualities such as inquisitiveness, intellectuality, quick thinking, deep thinking and wide-ranging general knowledge. Quite the opposite, they try to silence them, ignore them, and send a message to gifted pupils that these qualities are undesirable at school and interfere with their teachers' control of the normal teaching routine in the classroom. (3) Unintentional inappropriate behavior towards gifted pupils stemming from the teachers' lack of awareness of the difficulties experienced by gifted pupils and their special needs - wonderful on the one hand, and demanding on the other, as found by Hany (1997) in his research.

Eggen \& Kauchak (1994) emphasize, that mere placement in a heterogeneous class is not sufficient by itself for the advancement of any exceptional pupil. For the fulfillment of pupils' exceptionality teachers are required to invest time and efforts to develop and implement unique ways of working with unique pupils. The results indicate that this occurs insufficiently or not at all for the gifted pupils in the present study. Thus, it is not surprising that a great many complains emerged from the interviews with gifted pupils.

(4) The reactions and feelings of the gifted pupils at school, it was found that the gifted pupils do not function well at school, not in the scholastic aspects or in the behavioral ones: the older they are, the lower their scholastic situation and functioning, and their behaviors worsen.

According to a UNESCO report, many countries throughout the world are trying to advance laws and regulations to mainstream 'different' pupils and at the same time provide unique treatments for each population (UNESCO, 1996). These usually refer primarily to pupils with low achievements due to learning disabilities, and do not address the population of gifted pupils. Reacting to such claims, Feldhusen \& Moon (1992) suggest that justice can be achieved not by providing equal treatment for different children but by providing equal opportunities for each child to progress. Thus, gifted pupils should receive support and special treatment as needed for their talents. The results of the present study can motivate teachers to adopt the claim of Feldhusen \& Moon, and try to provide different educational opportunities for high-ability pupils within the heterogeneous classes. Pupils' social and academic situations within the classroom are interconnected; hence, good treatment for either can impact the other. Establishing good relations with their gifted pupils by providing attention and care can help these special pupils to maintain good relations with their peers and to fulfill their academic potential.

The literature provides a wealth of recommended methods on how to address such difficulties of gifted pupils within the heterogeneous 'regular' classes, which are no more difficult to apply than the methods used to treat other unique groups. Gifted pupils do not comprise a large group in terms of the percentage they constitute in each heterogeneous classroom. However, the possible harm to them resulting from difficult interactions with each part of the system may cause problems, the cumulative damage of which to each of these children in particular, and to the promotion of excellence as a national value in general, is liable to be very serious indeed.

\section{$\underline{\text { Part II }}$}

(5) Professional Knowledge gained by pre-service teachers. The findings of the present study corroborate the assertions of researchers such as Gross (1993), Archambault et al. (1993) and Croft (1999), according to which part of the problem of gifted pupils in the system stems from the teachers' lack of appropriate professional knowledge about what they should do with these pupils, and from their lack of awareness of the difficulties experienced by gifted pupils in the system. Almost $1 / 2$ of the pre-service teachers reported in their reflections that although they were not surprised, they did learn new things, previously unknown to them, about the situation of gifted pupils and their needs. About $1 / 3$ of them not only learned new things, but were also surprised. In other words, what they heard in the interviews contradicted their expectations, their previously held perceptions of giftedness and/or their previous knowledge about the situation of gifted pupils in heterogeneous classes. 1/3 of the beginner teachers related in the reflections that they gained an understanding following the interviews that gifted pupils have special needs and experience unique difficulties. About $1 / 3$ of them gained insights following the interviews into their own behavior and their desired behavior as teachers in heterogeneous classrooms, and 1/3 gained both types of insight. Hence, learning about gifted pupils in heterogeneous classrooms is essential and constitutes an integral part of teacher training. Although they were already in their second year of teacher training and had been exposed to teaching in heterogeneous classrooms for two years, and although they themselves had studied in heterogeneous classrooms, the 
focus on the subject raised their awareness of the difficulties experienced by gifted pupils, and their special needs as special pupils. Moreover, they gained insights into their own behavior as teachers: What they should not do, what they should do, and how.

The literature provides a wealth of recommended methods on how to address such difficulties of gifted pupils within the heterogeneous 'regular' classes, which are no more difficult to apply than the methods used to treat other unique groups. Gifted pupils do not comprise a large group in terms of the percentage they constitute in each heterogeneous classroom. However, the possible harm to them resulting from difficult interactions with each part of the system may cause problems, the cumulative damage of which to each of these children in particular, and to the promotion of excellence as a national value in general, is liable to be very serious indeed. Teachers can gain the necessary professional knowledge about these issues, and as the present study shows, this can be accomplished in the course of their training.

\section{REFERENCES}

1. Archambault, F.A., Westberg, K. L., Brown, S. W., Hallmark, B. W., Emmons, C. L., \& Zhang, W. (1993). Regular classroom practices with gifted students: Results of a national survey of classroom teachers (Research Monograph 93102). Storrs, CT: The National Research Center on the Gifted and Talented, University of Connecticut.

2. Buescher, T.M., \& Higham, S. (1990). Helping adolescents adjust to giftedness. Clearinghouse on Disabilities and Gifted Education. On Line located at: http://ericec.org/digests/e489.html

3. Croft, L. (1999). Six Maddening Myths of Gifted Education. On Line located at: www.uiowa.edu/ itag/myths.html

4. $\quad$ Eggen, P., \& Kauchak, D. (1994). Educational Psychology: Classroom Connections (2nd ed.). N.J: Prentice-Hall, Inc.

5. Eyre, D. (2004). Structured Tinkering: Improving Provision for the Gifted in Ordinary Schools. The National Academy for Gifted and Talented Youth (NAGTY). The University of Warwick: Department for Education and Skills. On Line located at: http://www.warwick.ac.uk/gifted/professionalacademy/downloadable-materials/documents/structured-tinkering.doc

6. $\quad$ Feldhusen, J.F. (1986). A conception of giftedness: A developmental model for creative productivity. In R. J. Sternberg, J. E. Davidson (Eds.), Conceptions of Giftedness. (pp. 112-127). New York: Cambridge University Press.

7. $\quad$ Feldhusen, J.F. (1996). How to identify and develop special talents. Educational Leadership, 53(5), 66-69.

8. Feldhusen, J. F., \& Moon, S. M. (1992). Grouping gifted students: Issues and concerns. Gifted Child Quarterly, 36, 63-67.

9. $\quad$ Freeman, J. (1998). Educating the Very Able. Current International Research. OFSTED Reviews of Research. On Line located at: http://www.archive.officialdocuments.co.uk/document/ofsted/veryable/able.htm

10. Freeman, J. (2001). Educating the Very Able: Current International Research. On Line located at: http://www.archive.official-documents.co.uk/document/ofsted/veryable/able.htm.

11. Gage, N.L., \& Berliner, D.C. (1992). Educational Psychology (5 ${ }^{\text {th }}$ ed.). Boston: Houghton Mifflin.

12. Gagné, F. (1993). Constructs and models pertaining to exceptional human abilities. In K.A. Heller, F.J. Mönks \& A.H. Passow (Eds.), International handbook of research and development of giftedness and talent (pp. 69-88). Oxford: Pergamon Press Ltd.

13. Gallagher, J., Harraine, C.C., \& Coleman, M.R. (1997), Challenge or boredom? Gifted students' views on their schooling. Roeper Review, 19(3), 132-136.

14. Gardner, H. (1983). Frames of Mind: The Theory of Multiple Intelligences. New York: Basic Books.

15. Gorodetsky, M. \& Klavir, R. (2003). What do gifted/non-gifted problem solvers do? Learning and Instruction, 13(3), 305-325.

16. Gross, M.U.M. (2000). Exceptionally and profoundly gifted students: an underserved population. Understanding Our Gifted, 12 (2), 3-9.

17. Hany, E. A. (1997). Modeling teachers' judgment of giftedness: A methodological inquiry of biased judgment. High Ability Studies, 7(2), 159-178. 
18. Hébert, T.P. (2000). Defining belief in self: intelligent young men in an urban high school. Gifted Child Quarterly, 44(2), 3-9.

19. Herrnstein, R.J. \& Murray, C. (1994). The Bell Curve: Intelligence and Class Structure in American Life. New York: The Free Press.

20. Hunt, E. (1995). The Role of Intelligence in Modern Society. American Scientist, 83(4), 356-368.

21. Kearney, K. (1993). Discrimination against Excellence. Understanding Our Gifted, 6 (2), 16-18.

22. Klavir, R. (2001). What is Excellent in Excellence: A model for the analysis of problem solving by gifted, experts, and other groups. Unpublished doctoral dissertation, Ben-Gurion University, Beersheba, Israel.

23. Klavir, R. \& Gorodetsky, M. (2001). The processing of analogous problems in the verbal and visualhumorous (cartoons) modalities by gifted/average children, Gifted Child Quarterly, 45 (3), 205-215.

24. Lee, V.E., \& Smith, J.B. (1993). Effects of school restructuring on the achievement and engagement of middle-grade students. Sociology of Education, 66(3), 164-187.

25. Milgram, R.M. (1989). Teaching Gifted and Talented Learners in Regular Classrooms. Springfield, Il.: Charles C. Thomas.

26. Moon, R.T., Callahan, C.M. \& Tomlinson, C.A (1999). The Effects of Mentoring Relationships on Preservice Teachers' Attitudes Toward Academically Diverse Students, Gifted Child Quarterly, 43 (2), $76-85$.

27. NATO-UNESCO (2002) Science Education: Talent Recruitment and Public Understanding. On Line located at: http://www.chaperone.sote.hu/natowork

28. Parke, B. (1992). Challenging gifted students in the regular classroom. The ERIC Clearinghouse on Disabilities and Gifted Education: The Council for Exceptional Children. On Line located at: http://www.ericfacility.net/databases/ERIC_Digests/ed352774.html

29. Reis, S. M. (1989). Reflections on policy affecting the education of gifted and talented students: Past and future perspectives. American Psychologist, 44(2), 399-408.

30. Renzulli, J.S., \& Reis, S.M. (2002). What is schoolwide enrichment and how do gifted programs relate to total school improvement? Gifted Child today, 25 (4), 18-25.

31. Rogers, K. B., \& Span, P. (1993). Ability grouping with gifted and talented students: Research and guidelines. In K. Heller, F. Mönks, \& A. H. Passow, (Eds.), International handbook of research and development of giftedness and talent (pp. 585-592). Tarrytown, NY: Pergamon Press.

32. Shore, B.M. \& Kanevsky, L.S. (1993). Thinking Processes: Being and Becoming Gifted. In K.H. Heller, International Handbook of Research and Development of Giftedness and Talent, (pp. 133-147). Oxford: Pergamon Press.

33. Tannenbaum, A.J. (1983). Gifted Children: Psychological and Educational Perspectives. New York: Macmillan.

34. UNESCO. (1996). UNESCO Survey on Special Needs Education Law. CSIE (Centre for Studies on Inclusive Education) summary. On Line located at: http://inclusion.uwe.ac.uk/csie/unscolaw.htm

35. Van Tassel-Baska, J. (1992). Educational decision making on acceleration and grouping. Gifted Child Quarterly, 6 (2), 68-72.

36. Van Tassel-Baska, J. (2001). Basic Educational Options for Gifted Students in Schools, College of William and Mary. On Line located at: http://cfge.wm.edu/Articles/Basic Educational_Options.htm.

37. Woolfolk, A. E. (1995). Educational Psychology (6 ${ }^{\text {th }}$ ed.). Boston: Allyn and Bacon.

38. Ziv, A. (1990). Gifted pupils. Tel-Aviv: Keter (Hebrew). 